\title{
Owners and CEOs of Startups: Evidence from Russia
}

\section{Olga Guseva}

$\mathrm{PhD}$ student

$\underline{\text { ORCID }}$

E-mail: oguseva@hse.ru

Doctoral School of Economics, National Research University Higher School of Economics, Moscow, Russia

\author{
Anastasia Stepanova \\ Associate Professor, Research Fellow \\ $\underline{\text { ORCID }}$ \\ E-mail: anstepanova@hse.ru
}

HSE School of Finance, National Research University Higher School of Economics, Moscow, Russia Corporate Finance Center, National Research University Higher School of Economics, Moscow, Russia

Journal of Corporate Finance Research, Vol. 13, No. 1, pp. 107-119 (2019)

DOI: https://doi.org/10.17323/j.jcfr.2073-0438.13.1.2019.107-119

Received 31 January 2019 | Peer-reviewed 15 February 2019 | Accepted 5 March 2019 


\section{Owners and CEOs of Startups: Evidence from Russia}

\section{Abstract}

In this paper, the authors focus on two primary governance mechanisms which can be considered as sources of support for startup companies: the company's ownership contingent and the company's management personnel. Based on descriptive statistics from a sample of 416 Skolkovo start-ups from the 'Nuclear' and 'Space' clusters, and a Start-up-Barometer survey of 300 IT-entrepreneurs, this work provides new insights into ownership and management characteristics of Russian startups and the interplay between these dynamics.

The Russian venture market presents an interesting case of an emerging market with a number of successful startups in a challenging economic environment. The supply of venture capital for Russian startups is restricted by the presence of sanctions and legal restrictions on the investments of financial institutions such as pension funds and banks. Therefore, similar to other developed and developing markets, the most significant source of investments for Russian startups is bootstrapping.

In this paper we show that startups with different characteristics attract different kinds of investors, which is reflected in the companies ownership structures. In particular, government development institutes are more interested in investing in nuclear-focused startups, while corporate investors tend to keep a higher level of control over startups compared to other investors. We also confirmed the presence of correlations between different types of owners: government development institutions, corporate investors, venture funds, and family members. Additionally, the size of equity share for all types of owners (except family members) was found to be negatively correlated with the CEO's share in the ownership structure.

Although the purpose of the article is descriptive, it motivates further research on the sources of support of startup growth, including relative importance of such sources and their effects on startup performance.

Keywords: startups, ownership, management, emerging markets

JEL classification: G32, M13, O32 


\section{Introduction}

At the beginning of 2019, most of the biggest companies in Russia have already expressed their interest in investing in new technologies. Some companies (such as Rostec and Sberbank) have created special divisions which are responsible for searching for potential venture investments, others (such as Rzhd and X5 Retail Group) have invested money in funds managed by other parties. Moreover, according to a project of a strategy for venture capital market development announced by Russian Venture Company and the Ministry of Economic Development of the Russian Federation, the size of the market for financing venture capital projects is expected to grow by a factor of 10 to 2,7 trillion of rubles by 2030 [1].

However, do such equity investments provide value for such big corporations? According to recent studies by Rossi et al. [2], such investments should not be considered only as financial activities aimed at producing high returns, but also as incentives for strategic innovations for the investing companies. Furthermore, academic literature supports the importance of new technology firms for economic growth by increasing efficiency of economic activities, improving the employment situation, improving social mobility, and promoting competition $[3,4,5]$. Such evidence as to the benefits of startup activities for private and government entities motivates further research on the support of startup growth, including in the context of emerging markets.

In this paper, we are going to focus on two main features of startups which can be considered as sources of support: those characteristics exhibited by a startup's ownership, and those of the management structure. It should be mentioned that traditionally, debt financing plays an important role for new firms. According to Hirsch et al. [6] bank financing is significant for new ventures in France at the very beginning of the company's life, but its significance diminishes over time. Hanssens et al. [7] found that leverage ratios for a sample of Belgian startup firms were higher compared to the sample for all firm-year observations. In the study of Coleman et al. [8], 57\% of the sample of newly-formed businesses in the United States used debt in their capital structure.

At the same time, according to the study of Minola et al. [9], financing of new technology-based firms is influenced by higher information asymmetry and correspondingly, equity financing for such firms occurs prior to debt. Indeed, according to Start-up-Barometer 2018 (organised by venture investor Alexey Solovyev in cooperation with the Internet Initiatives Development Fund and EY), in a survey of around 300 IT-entrepreneurs, $0 \%$ of startups in Russia were found to have used loans from banks as initial source of financing[10].

The academic literature on the management of startups as well as their ownership structure, especially in developed markets, is extensive; however, the question of the relative importance of these two sources of startup support on performance, as well as interaction between them, is yet to be discussed. In this paper we are going to provide new insights about the ownership and management characteristics of Russian startups and will analyse some correlations observed between these features.

\section{Description of startups in Russia}

The venture capital market in Russia is small in comparison with the venture capital market of developed and developing countries: in particular, according to research by Russian Venture Capital Association (RVCA) during 2017 there were 178 venture capital investments with a total volume of 125 million dollars in Russia (less than $0.1 \%$ of total volume of global venture capital investments, which totaled 155 billion dollars in 2017), while in the US in 2017 more than 83 billion dollars were invested in venture capital market. In China, the figure accounted for more than 40 billion dollars [11, 12].

The typical characteristics of financing for Russian startups also have some specific features which are more similar to developing countries than developed ones. Traditionally, the share of investments in the IT sector in terms of total venture capital investments is highest (in 2017 the share was 58\% in Russia and 56\% in Asia, as opposed to $46 \%$ in Europe and $40 \%$ in the US), while share of investments in healthcare and biotech is smaller (in 2017, the figure was 7\% for Russia, 5\% in Asia, 20\% in Europe, and 25\% in the US) [11, 12].

According to the research of Start-up-Barometer 2018 [10], the average Russian startup business has already existed for 3 years and is currently at the stage of the development of the product. $34 \%$ of startups that participated in the survey still do not have any revenue, while for $23 \%$ revenue is below 1 million rubles. Another interesting feature of a Russian IT startup is that the main source of financing is founders' capital. $71 \%$ of startups in the sample are financed from their own resources, while the second most popular source of financing is friends/family/or private non-professional investors.

In order to expand the selection of Russian startups, we also constructed our own sample of Russian startups from Skolkovo's Nuclear and Space clusters, which were participants in the Skolkovo innovation system in June 2018. Skolkovo's Space cluster startups are engaged in the development of telecommunication, navigation and geo-information products, space and aviation technologies, and those in the Nuclear cluster include startups which are engaged in the development of technologies based on nuclear science developments and related characterisation of materials. In our data sample by the end of 2017, there were 207 startups in the Space cluster and 209 startups in the Nuclear cluster. The data about the main characteristics of the startups was manually collected using the 'Spark' system, which was established by Interfax, a major Russian news and information group. The descriptive statistics of the collected sample are presented in Table 1.

In the context of the topic of this paper, our data sample supports the point that ownership and management are 
different sources of startup support, which are separate and distinct. In particular, in our sample, the average share of the CEO in the ownership structure is $43 \%$. At the same time, the ownership structure of the startup from our sample is quite concentrated: the average top share holding amounts to $73 \%$, while the top three share holdings account for $95 \%$ of ownership.

Most of these startups are located in Moscow and the Moscow region (including Skolkovo), accounting for 301 out of 416 startups. Additionally, 25 startups were situated in Saint-Petersburg, 13 in the Nizhny Novgorod region and 11 in the Novosibirsk region. It should be mentioned that those regions have been traditionally considered centers of scientific research since the Soviet period. Besides, according to The State of European Tech [13], Moscow holds seventh place among European cities in terms of the number of venture-backed companies

Moreover, as presented in Graph 1, there are notably less startups still in existence $4-5$ years after founding. This means that most startups in our sample were established before 2013 or after 2014, which corresponds with the crisis period in the Russian economy observed during 2014 and 2015 (the age distribution of startups in our sample is presented in Graph 1).

Graph 1. Age distribution of startups of Skolkovo startups from Nuclear and Space clusters in 2017

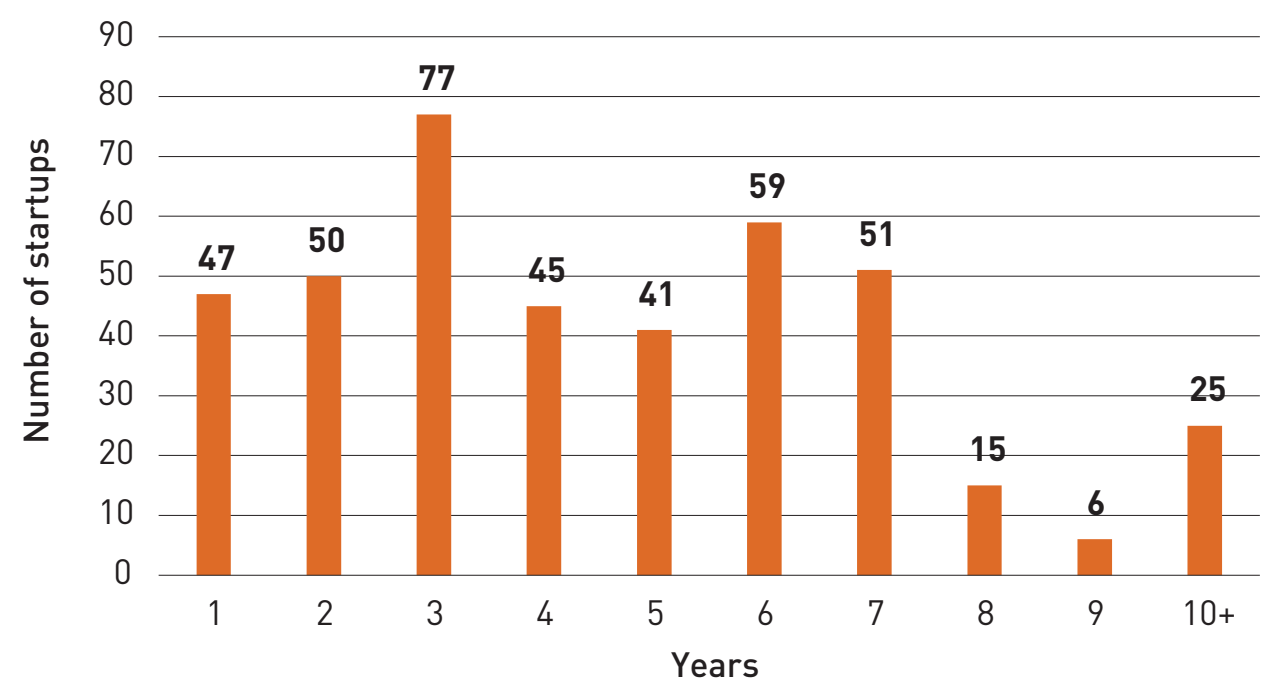

Table 1. Descriptive statistics of Skolkovo startups from Nuclear and Space clusters in 2017

\begin{tabular}{|c|c|c|c|c|c|}
\hline & $\mathbf{N}$ & Mean & Median & Standard deviation & $\operatorname{Max}$ \\
\hline Number of owners & 416 & 2,4 & 2 & 1,77 & 10 \\
\hline Number of female owners & 416 & 0,2 & 0 & 0,41 & 2 \\
\hline Biggest share & 416 & 0,7 & 0,8 & 0,27 & 1 \\
\hline CEO share & 416 & 0,4 & 0,4 & 0,40 & 1 \\
\hline
\end{tabular}

\section{Ownership structure of Russian startups}

As it was discussed previously, revised pecking-order theory predicts that equity is the main source of startup financing (due to high intangibility of assets) and therefore results in high information asymmetry and scarcity of collateral. Indeed, the majority of papers about entrepreneurial finance focus largely on equity finance [14, p. 552]. Additionally, participation in the ownership structure gives investors an instrument of influence on the performance of the firm [15]. Therefore, the type of the owner that defines his or her strategy can have a great impact on the development of the company.

\section{Entrepreneurs as founders and owners}

As was discussed in the second part of the article, the initial source of funding for the majority of startups in Russia are the personal resources of the founders. According to Start-up-Barometer [10], the average founder of startup in Russia is a 30-32 year old male with a technical/ engineering education who most likely has already had a negative experience of project failure or business closure. The personality of the entrepreneur plays an extremely important role in the success of the newly founded ventures: both in terms of psychological traits and in terms of the skills and knowledge of the founder [16]. Moreover, this personality has an influence on the financing of the company in the future: for example, Banerji et al. [17] 
demonstrated that the number of a founders' followers on LinkedIn is the strongest predictor of the amount of funds that will be raised by the new companies.

The Start-up-Barometer 2018 survey [10] showed that $69 \%$ of ventures were founded by two partners, while in our sample of Skolkovo startups from Nuclear and Space clusters, around $45 \%$ of startups were established by a single entrepreneur (with 18\% having been founded by two entrepreneurs, and $11 \%$ by three entrepreneurs). Taking into account certain specifics of the space and nuclear industries, this discrepancy between the samples partially supports the findings of Kim et al. [18] (based on a sample of American entrepreneurs), that indicated founders with more venture-specific industry experience are less likely to engage and collaborate with other people during the early stages of the business.

In most startups from the Skolkovo sample, the initial founders still maintain a share in the ownership structure. Out of 416 startups, only 50 completely changed owners, while the rest of still maintained founders who have some control over the startup. However, according to the study by Wasserman [19] of 6,130 startups between 2005 and 2012, companies in which the founder has given up control are more valuable compared to those in which the founder is still in the CEO position or is in control of board of directors.

According to the dataset collected by Wasserman [19], the mean and median number of owners in American startups is equal to 2.7 and 2 respectively. This is similar to our dataset of Skolkovo startups: according to Table 1, the mean of number of owners in startups is 2.4 , and the mean is 2 .

However, the gender diversity situation in Russian startups is different from startups in developed markets. For example, only $15 \%$ of our Skolkovo sample (62 out of 416 startups) had at least one female owner and only $6 \%$ had woman CEO, which is significantly lower than the $42 \%$ share of female governance startups in the total population of innovative startups in Italy [20]. However, even in developed markets, the situation with gender diversity in startups is far from perfect. According to a recent survey for The State of European Tech [13], all-male founded teams received 93\% of the investments in the European tech industry 2018.

\section{Family and friends}

According to the vast entrepreneurship literature, family and friends are a very significant source of startup initial funding, which provide the entrepreneur with moral support, mentoring, expertise and contacts [21]. Conti et al. [22] showed that money from friends and family can be considered not only as financial support but rather a signal about a startup, as friends and family members are supposed to have insider information about the company. Therefore, the owners of startups use family and friends' money to attract 'angel' business investments.

Family ownership can also have an influence on a startup's capital structure. For example, Schmid [23] showed that family-owned firms have lower leverage (based on a sample of German firms). Such results led authors to the conclusion that entrepreneurs and their families use more equity financing in order to improve control over the company.

However, according to Coleman et al. [8] the firms' and founders' individual characteristics also have an influence on the decision to use financing from such informal sources: for example, firms with high-growth prospects (as well as less educated entrepreneurs) were found to have more personal funding, especially in forms of loans from family and friends.

Taking into consideration the underdevelopment of Russian financial markets compared to developed countries, we can suggest that money from family and friends is expected to be one of the main sources of financing for Russian startups. Indeed, according to Start-up-Barometer 2018, money from such informal sources was the second most popular source of IT-startup funding in Russia ( $11 \%$ of the sample) after bootstrapping (71\%). The results from the Skolkovo sample of Space and Nuclear startups showed that only $7 \%$ startups have family members in their ownership structure. However, given that there are still a lot of unsolved legal matters regarding the ownership of intangible assets (such as knowledge and managerial expertise) [24], the real share of family and friends in startup support could be higher.

According to Entis [25], 38\% of US startups receive funding from family and friends, while $57 \%$ of startups were founded on entrepreneurs' personal money. However, we should keep in mind that such difference between a mix of personal and family/friends financing could be explained by institutional differences: funding by family and friends for Russian startups does not always involve legal arrangements. Therefore, the funding could be loaned to a startup founder as his personal debt which he/she invests in the business.

\section{Corporate investors from industry}

Although the majority of startups were founded by individuals, $25 \%$ of startups (105 entities) from our sample of Skolkovo participants were founded by or in cooperation with an industry company. In the later stages of a startup's life the level of participation of companies from the relevant industry in the startups increases: as of 2017, 31\% of the startups had a company in its ownership structure with an average share of $20.6 \%$, which makes such companies the main source of equity funding for startups (see Table 2).

At the same time, corporate investors also significantly benefit from investing in new technology ventures. According to Benson et al. [26], although corporate investors differ in their ability to derive benefits from venture capital investing, consistent engagement in such investments can improve the performance of a corporate investor by increasing returns alongside as well as increasing the $R \& D$ productivity of the company. 
Table 2. Who is inside the ownership structure of a Russian startup in 2017?

\begin{tabular}{|c|c|c|c|c|c|}
\hline & $\begin{array}{l}\text { Number of startups with owner } \\
\text { type in ownership structure }\end{array}$ & Mean & Median & St. dev. & $\operatorname{Max}$ \\
\hline Company & 129 & $20,6 \%$ & $0 \%$ & 0,362 & $100 \%$ \\
\hline $\begin{array}{l}\text { Government development } \\
\text { institutes }\end{array}$ & 76 & $7,1 \%$ & $0 \%$ & 0,193 & $100 \%$ \\
\hline Family members & 28 & $6,7 \%$ & $0 \%$ & 0,251 & $100 \%$ \\
\hline PE/VC & 13 & $1,5 \%$ & $0 \%$ & 0,104 & $100 \%$ \\
\hline
\end{tabular}

Additionally, it should be mentioned that becoming a Skolkovo participant has some advantages in terms of legal and tax issues for a young company. In particular, the status of a Skolkovo participant allows one to avoid income tax, VAT, as well as payment of customs duties, and gives an opportunity to apply for a grant. Therefore, such benefits can motivate big corporations to separate their R\&D departments into a separate entity based in Skolkovo and can potentially explain the high amount of startups fully-owned by corporate investor, which is around 13\% of our Skolkovo sample.

Besides this, alongside the corporate investors of Skolkovo startups, there are government-affiliated companies such as Rosatom State Nuclear Energy Corporation, The Roscosmos State Corporation for Space Activities, and the state corporation «Rostec» and their subsidies. However, taking into account the leadership of these state companies in the space and nuclear industries, their participation in the ownership structure of startups is in line with their strategic aims.

\section{Government development institutes}

According to the report published by the Federal Antimonopoly Service of the Russian Federation in 2016, government and government companies control around $70 \%$ of the Russian economy, and that creates monopolistic trends in the economy [27]. Therefore, the government of the Russian Federation is supposed to be the one of the main investors in all sectors, including technology and R\&D.

Indeed, in 2017, 194 venture funds operated in the Russian market, including 54 funds with government capital, with a total volume of $888 \mathrm{mln}$ dollars (22\% of total volume of 4,071 mln dollars of VC funds in Russia) [11]. The sectors in which these fund investments are different compared to private fund investments. For example, in $2017,66 \%$ of investments with government capital were made into the industrial sector, $23 \%$ to the IT-sector, and $11 \%$ to biotech startups. At the same time, only $2 \%$ of investments of private VC funds were made into the industrial sector, $5 \%$ into biotechnologies, while the IT-sector attracted $74 \%$ of the total investments of private VC funds in Russia.
Overall, currently there are many institutes providing government support for startup activities (which we are going to refer to henceforth as government institutes of development). These are government venture capital funds, public universities (including university incubators) and other development institutes which are aimed at filling the gaps left by market failures. In particular, such institutes are supposed to catalyse financing from private investors and create the necessary infrastructure for startups, including access to equipment.

Among the most active government development institutes which are focused on innovative technology (and involved in venture financing) are:

- Russian Venture Company (founded in 2006, government funding of 30 bn rubles) and Rusnano (founded in 2007, government funding of more than 300 bn rubles) both which operate as "funds of funds";

- Skolkovo Innovation Centre (founded in 2010, government equity funding of more than 100 bn rubles) including Skolkovo City, and technoparks;

- Fund of Innovations promotion (FASIE) (founded in 1994).

Although the government funding of development institutes seems excessive, there are countries which invest in high-technology startups more heavily. For example, the Chinese national venture capital fund for emerging industries was established in 2015 and had government funding of 5,84 mn dollars [28]. By 2016 the Chinese government has set aside more than 320 bn dollars for investment in the technology sector [29].

In our sample of Skolkovo participants, $12 \%$ of startups were founded by or in cooperation with at least one institutional founder (a category in which we include government development institutions and private equity and private venture capital funds). However, if we consider not only the founding year of a startup, but the later stages of the life cycle of a startup the participation of government institutions increases: 19\% of startups have institutional representation in the ownership structure.

Academic institutions represent an important group of government development institutes: for example, around 
$30 \%$ of business incubators are linked to universities [30], and are mostly designed for the support of students' ideas. As most of the universities in Russia are financed from the government budget, we consider them to be government development institutes.

However, although the quality of Russian university-linked business incubators and accelerators is comparatively good (according to UBI Global, 2 out of 20 top business incubators managed by universities are from Russia [31]), they are mostly focused on providing different kinds of support to startups (such as expertise and opportunities for networking) rather than direct funding. Therefore, we cannot track the significance of these entities in the ownership structure of startups. Indeed, according to Startup-up-Barometer 2018 , only $2 \%$ of respondents obtained initial financing from accelerators [10].

University incubators are widespread not only in Russia, but in other developing and developed countries. Indeed, the youngest entrepreneurs are the ones who need the most support. A recent study by Azoulay et al. [32], based on a sample of 2.7 million founders showed that the average age of a successful startup founder is 45 years old, while people under 29 have the lowest likelihood to found a successful startup.

We should point out that according to Venture Barometer 2018 [33] (a survey of 88 venture investors), in 2017 $44 \%$ of respondents considered government development institutes to be a potential source of funding for venture investments, while in 2018 their share decreased to only $15 \%$. Government corporations were considered even less attractive: in 2018 only $11 \%$ of venture investors mentioned them in the survey, while the role of private capital increased from 2017 to 2018 [33, p. 10]. This may be a sign of a changing trend in the minds of the Russian venture industry: from confidence in government funding to hope for private investments.

\section{Private equity and venture capital funds}

Venture capital and private equity funds are considered to be one of the main sources of startup support. According to Davila et al. [34] support of venture capital in the form of funding gives a significant positive signal about a startup which can encourage its further growth. Fitza et al. [35] showed that venture capital "can bring legitimacy, prestige, governance expertise, social networks, management ability, and knowledge related to a start-up's technological or market foundations." [35, p. 401].

However, results of the Start-up-Barometer 2018 (as well as descriptive statistics of our Skolkovo sample startups) showed that only $3 \%$ of startups in Russia had financing from venture funds. These figures are partially explained by the small size of the venture capital market. The total volume of venture investments in Russian startups represent less than $0.1 \%$ of the global total. Indeed, while the total volume of VC investments in Russia during 2015-2017 was around $400 \mathrm{mn}$ dollars [11], there were 80 mega-deals of $500 \mathrm{mn}$ dollars or more in China during the same period of time [36]. However, even in developed markets such as the US, only $5 \%$ of startups are funded by VC while the average size of such funding is bigger compared to other sources [25].

Additionally, while $3 \%$ of startups have venture capital financing (both in our sample of Skolkovo startups and in the sample of IT startups), $5 \%$ of these have funding from business angels, who are considered to be the most attractive investors for startups ( $85 \%$ of startups are interested in investments from high-net-worth-individuals and family offices). However, such investments are very difficult to track in comparison to the government development institutes and companies funding.

Venture Barometer 2018 [33] showed that along with a decrease in the attractiveness of government financing among venture funds themselves, Russian investors are becoming more interested in foreign financing. In particular, the share of venture capitalists interested in investments from foreign institutional funds increased from $3 \%$ to $13 \%$, while the third most attractive group of investors consisted of institutional investors from Asian and Arabic countries: (32\%).

However the trend also works the other way: according to the survey of Russian investors in Venture Barometer $2018,57 \%$ of investors made new venture investments in other countries. This also influenced the Russian venture capital market as it decreased the supply of capital.

Taking into account the aforementioned statistics on the ownership structures of Russian startups, we can make several conclusions about specific features observed in the Russian market of new-technology venture financing. First, the Russian venture capital market represents a very small part of the global venture capital market, which motivates Russian venture investors to seek funding from foreign institutions and companies.

Second, government funding represents a significant source of support for startups in Russia compared to those in developed countries. However, we should keep in mind the differences in goal setting. While private investors are interested in financial returns from the investments, government development institutes support the startups which could potentially benefit strategic government interests. This also explains the active participation of government development institutes in particular sectors such as the nuclear and space industries.

Third, on the Russian financial market there are certain limitations for participation of pension funds, insurance companies and banks in new-venture financing, while in the European market up to $15.5 \%$ of funds committed to VC funds come from these types of investors [13]. However, in the project of a strategy for venture capital market development announced by the Russian Venture Company and the Russian Ministry of Economic Development, the share of pension funds, insurance companies and corporate investors' financing in total venture fund capital should reach up to $45 \%$, while government's share should compose just $30 \%$ [1]. 
Fourth, underdevelopment of financial markets also promotes the appearance of a number of business angels on the Russian markets. According to Sakovich (the managing director of Skolkovo Ventures) currently there are more than 10,000 business angels in Russia, most of whom are top-managers and owners of SMEs [37]. This explains the much higher share of business angel financing in Russia comparing to developed markets (see Table 3 ).

Table 3. Main funding sources of Russian and US startups

\begin{tabular}{|c|c|c|}
\hline $\begin{array}{l}\text { Source } \\
\text { of funding }\end{array}$ & $\begin{array}{l}\% \text { of US } \\
\text { startups } \\
(2012)\end{array}$ & $\begin{array}{l}\text { \% of Russian } \\
\text { IT startups } \\
(2018)\end{array}$ \\
\hline Personal savings and loans & $57 \%$ & $71 \%$ \\
\hline Family and friends & $38 \%$ & $11 \%$ \\
\hline Venture capital & $5 \%$ & $3 \%$ \\
\hline Angel investments & $0,91 \%$ & $5 \%$ \\
\hline Banks & $1,43 \%$ & $0 \%$ \\
\hline
\end{tabular}

Source: Fundable.com, Start-up-barometer 2018

Fifth, the size of the crowdfunding market (which is another potential source of financing for startups in Russia) is small despite outperforming growth rates. In 2017 the total value of crowdfunding was 11.2 bn rubles, while P2P lending in China surpassed the threshold of $100 \mathrm{bn}$ dollars in 2016 [38]. Therefore, the development of this segment can also potentially be a source of significant support for Russian startups.

\section{Management of Russian startups}

Management represents a different type of support which can significantly influence the performance of a firm, especially in young firms which have limited prior experience and expertise [39]. Moreover, top management can bring not only knowledge and networking opportunities, but in the case of a startup, it appears to be a decision-making body for the most important decisions of a firm, such as closing the company or deciding to sell to provide an appropriate exit for investors [40].

Therefore, the academic literature on the influence of top-management characteristics on firm performance is extensive. In particular, Barker et al. [41] found a positive relationship between firms' R\&D spending and CEO characteristics (such as age, or previous careers in marketing and engineering). Telaia et al. [42] showed that there is a direct relationship between the ability of CEO to raise funds and his/her education, which gets stronger in cases where the CEO has anMBA degree. Stepanova et al. [43] confirmed that a higher share of independent directors has a positive correlation with higher R\&D investments, as the presence of such directors mitigates the agency problem.

However, the data on top-management of startups is limited. Most of the journal literature focuses on found- ers' profiles rather than on CEOs. The roles of a CEO and founder require a different set of skills, behaviours and motivations [44] and in many cases they are represented by two different people, even in startups. In our dataset of Skolkovo startups, while $23 \%$ of CEOs (96 out of 416 ) had $100 \%$ ownership, $30 \%$ of CEOs (123) did not have any share in the ownership structure of a startup. Moreover, the average share of a CEO was equal to $43 \%$, which also supports the idea that ownership and management should be analysed separately.

Regarding the CEO profile, our dataset showed that out of 416 startups only 27 had a female CEO, which correlates with the $5 \%$ figure for companies with female CEOs in the Fortune 500 list [45]. As there is no proven investor response to the appointment of a female $\mathrm{CEO}$ or $\mathrm{CFO}$ significantly different from those cases where males are appointed [46], such a share could possibly reflect the effect of career choice between man and woman.

The change of a CEO can reflect the changes in a firm's performance. For new ventures, the reason for top management change was often found to be connected with both low and very high growth of the business [47]. In our Skolkovo sample, 39 out of 416 startups replaced their CEO. 16 of this number were startups, and represented companies in the second and third years of establishment, with 7 startups in the seventh year, which can reflect that these years define the later stages of startup life. The correlation between the change of CEO and other firm characteristics will be considered in the next section.

\section{Interaction between ownership and management characteristics}

In the previous sections of this paper we described different ownership and management characteristics observed for Russian startups based on a sample of 416 Skolkovo startups in the Space and Nuclear clusters in 2017. We should keep in mind the existence of potential selection bias in our sample: all the firms have already had a status of 'Skolkovo participant', which already suggests the presence of government support, and all of the firms are potentially subject to survivorship bias, as they lived through 2017.

However, even accounting for these potential biases, in our sample it is possible to observe significant differences among startups with different owners in their ownership structure. We constructed 3 subsets from our initial sample: (i) startups with the presence of corporate investors in the ownership structure, (ii) startups with government development institutes in the ownership, and (iii) startups where the CEO also has a share in ownership. The descriptive statistics of these groups (including the whole sample) alongside the general or median characteristics of startups are presented in Table 4.

Compared to the rest of the sample, corporate investors tend to invest in startups from the space industry, while government development institutes are more interested in research and development in the nuclear 
sector. Corporate investors, in contrast to government development institutes, are aimed towards taking control over startups: their median share in the ownership structure in the corresponding sample is $75 \%$, whereas for government institutes the figure is only $33 \%$. As such it may be stated that the ownership concentration in startups with corporate investors is significantly higher. Startups with a managerial ownership tend to be younger than the sample average, which is not necessarily surprising, as in the early stages of startup life these roles are played by the same person - generally the founder of the startup.

Table 4. Profile of a startup with median characteristics with different owners in the ownership structure (based on the sample of Skolkovo participants from Space and Nuclear clusters in 2017)

\begin{tabular}{|c|c|c|c|c|}
\hline & All sample & $\begin{array}{l}\text { Startups with } \\
\text { corporate } \\
\text { investors }\end{array}$ & $\begin{array}{l}\text { Startups with } \\
\text { government develop- } \\
\text { ment institutes }\end{array}$ & $\begin{array}{l}\text { Startups with } \\
\text { managerial } \\
\text { ownership }\end{array}$ \\
\hline Number of observations & 416 & 129 & 76 & 293 \\
\hline Share of startup from Space cluster & $50 \%$ & $51 \%$ & $31 \%$ & $49 \%$ \\
\hline Established & 2014 & 2013 & 2013 & 2014 \\
\hline Number of founders & 2 & 2 & 2 & 2 \\
\hline Number of owners & 2 & 2 & 3 & 2 \\
\hline Biggest share & $76 \%$ & $75 \%$ & $51 \%$ & $70 \%$ \\
\hline CEO share & $35 \%$ & $20 \%$ & $10 \%$ & $52 \%$ \\
\hline Share of corporate investors & $0 \%$ & $75 \%$ & $0 \%$ & $0 \%$ \\
\hline $\begin{array}{l}\text { Share of government development } \\
\text { institutes }\end{array}$ & $0 \%$ & $0 \%$ & $33 \%$ & $0 \%$ \\
\hline
\end{tabular}

Source: Authors' own calculations

Ownership and management are two primary governance mechanisms for the firm, and different combinations of these governance mechanisms can be used in order to solve principal-agency conflicts in the business [48] as well as to enhance the firm's performance. In particular, Colombo et al. [49] showed the number of owner-managers positively influences firm performance, while Cui et al. [50] found that there is $\mathrm{W}$-shaped relationship between managerial ownership and firm performance.

Although we cannot yet track the influence of different characteristics on performance due to the lack of financial indicators, Table 5 presents some particular insights between correlations of ownership with management characteristics with other related variables.

Managerial ownership was found to be negatively correlated with the participation of other investors in the ownership structure (especially corporate investors), which corresponds to the fact that in the early stages of startups' life cycles, most of the time the founder plays the roles of CEO and owner, a situation which changes as equity financing increases.

The binomial variable reflecting the change of CEO also has a negative relationship with CEO ownership, which indicates a strong interaction between management and ownership characteristics. Moreover, there is a positive and significant relationship between change of owner and change of CEO. This most likely indicates that new owners prefer to bring new management. However, surprisingly, we did not find a correlation between a change of CEO and the participation of government institutions, corporate investors, or venture funds.

Other management characteristics reflect the presence of female CEOs (binomial variable) which has a strong positive relationship with variables reflecting the number of women in the ownership structure of the company. However, female CEOs tend to have a lower managerial share.

Regarding the relationship between ownership characteristics, we noticed a number of strong correlations. As was stated previously, a positive relationship was found between family member ownership and the presence of PE/ VC in the ownership structure, which supports findings of Davila et al. [34] about the signaling theory of friends and family support for institutional investors.

Additionally, ownership concentration is influenced depending on the different types of owners. While the presence of government development institutes tends to dilute ownership concentration, the presence of a corporate investor tends to increase the size of the biggest share. Moreover, the presence of government institutes or corporate investors has a positive relationship between each other which could potentially mean that such investors prefer to share risks between each other. 
Table 5. Correlation matrix of ownership and management characteristics of Skolkovo participants from the Space and Nuclear clusters in 2017

\begin{tabular}{|c|c|c|c|c|c|c|c|c|c|c|c|}
\hline & $\begin{array}{l}\text { Number of } \\
\text { owners }\end{array}$ & $\begin{array}{l}\text { Number of } \\
\text { women owners }\end{array}$ & $\begin{array}{l}\text { Change of } \\
\text { owner }\end{array}$ & $\begin{array}{l}\text { Biggest share } \\
\text { direct }\end{array}$ & CEO share & Woman CEO & CEO change & Family members & $\mathrm{PE} / \mathrm{VC}$ share & $\begin{array}{l}\text { Government } \\
\text { development } \\
\text { institutes share }\end{array}$ & $\begin{array}{l}\text { Share of } \\
\text { corporate } \\
\text { investor }\end{array}$ \\
\hline Number of owners & 1,00 & 0,19 & 0,07 & $-0,78$ & $-0,33$ & $-0,03$ & $-0,06$ & 0,09 & 0,03 & 0,13 & $-0,15$ \\
\hline Number of women owners & 0,19 & 1,00 & 0,06 & $-0,19$ & $-0,09$ & 0,16 & 0,01 & 0,08 & $-0,03$ & $-0,06$ & $-0,16$ \\
\hline Change of owner & 0,07 & 0,06 & 1,00 & $-0,03$ & $-0,04$ & $-0,04$ & 0,17 & 0,03 & 0,10 & $-0,12$ & 0,00 \\
\hline Biggest share direct & $-0,78$ & $-0,19$ & $-0,03$ & 1,00 & 0,37 & 0,07 & 0,05 & $-0,12$ & 0,01 & $-0,15$ & 0,22 \\
\hline CEO share & $-0,33$ & $-0,09$ & $-0,04$ & 0,37 & 1,00 & $-0,07$ & $-0,14$ & $-0,03$ & $-0,09$ & $-0,29$ & $-0,40$ \\
\hline Woman CEO & $-0,03$ & 0,16 & $-0,04$ & 0,07 & $-0,07$ & 1,00 & 0,05 & $-0,03$ & $-0,02$ & 0,07 & 0,00 \\
\hline CEO change & $-0,06$ & 0,01 & 0,17 & 0,05 & $-0,14$ & 0,05 & 1,00 & 0,05 & 0,00 & 0,03 & 0,07 \\
\hline Family members & 0,09 & 0,08 & 0,03 & $-0,12$ & $-0,03$ & $-0,03$ & 0,05 & 1,00 & 0,10 & $-0,07$ & 0,04 \\
\hline $\mathrm{PE} / \mathrm{VC}$ share & 0,03 & $-0,03$ & 0,10 & 0,01 & $-0,09$ & $-0,02$ & 0,00 & 0,10 & 1,00 & $-0,01$ & $-0,02$ \\
\hline $\begin{array}{l}\text { Government development insti- } \\
\text { tutes share }\end{array}$ & 0,13 & $-0,06$ & $-0,12$ & $-0,15$ & $-0,29$ & 0,07 & 0,03 & $-0,07$ & $-0,01$ & 1,00 & 0,13 \\
\hline Share of corporate investor & $-0,15$ & $-0,16$ & 0,00 & 0,22 & $-0,40$ & 0,00 & 0,07 & 0,04 & $-0,02$ & 0,13 & 1,00 \\
\hline
\end{tabular}




\section{Conclusion}

In this article, we decided to focus on the description of ownership and management characteristics of startups as factors which have an influence on company performance. However, both management and ownership features are significantly influenced by economic and institutional factors observed in the country.

In particular, legal restrictions about the participation of certain groups of investors in venture financing decreases the supply of capital and creates bias in the ownership structure. Underdevelopment of financial markets (including P2P platforms) lead to higher participation of government development institutes and business angels. Economic sanctions imposed by the US were also reflected in the startup environment: while in 2012 US VC funds financed around 50 rounds of Russian startups, in 2017 zero startups disclosed venture rounds with investors from the US [51].

Still, the Russian venture market is extremely interesting. Despite a challenging economic situation in the country, Moscow and St Petersburg were found to be No. 2 and No 9 cities for fast growing private companies in the Inc. 500 Europe list [52]. Moreover, Rodionov and Gusamov [53] observed higher returns from venture capital and buyout deals on the Russian market compared to other BRIC countries. There are several factors contributing to a good environment for startups and their investors. These include good technical education (as a part of Soviet inheritance), low salaries expenses for qualified workforce, a comparatively low tax burden and significant support from government institutions.

Although the main sources of equity financing in Russian startups are similar to the ones observed on the developed markets, Russian technology-firms have a unique set of ownership structure characteristics, which include higher participation of government institutions and corporate investors. As we expected in the beginning, the most important sources of funding are informal: bootstrapping and family and friends.

Moreover, we found evidence that startups with different characteristics attract different investors, which is reflected in their ownership and management structure. For example, space sector startups attract more corporate investors, while government institutes are more interested in firms from the nuclear sector. Startups with the presence of corporate investor in their ranks also tend to have a more concentrated ownership structure, while the presence of government investors has the opposite effect.

Additionally, we confirmed the relationship between different kinds of owners. In particular, we found that there is a positive relationship between the participation of corporate and government investors, which can reflect the close connection between government and corporate activities and indicate a risk-sharing pattern in the behaviours of such investors. At the same time, we found support for negative correlation between managerial ownership and ownership by companies and institutions. However, we should bear in mind that the use of correlations has a number of limitations, including the inability to find a causal relationship. Overall, in our paper we aimed to show that the institutes of management and ownership play an important role in a startup's life at different stages of its development, although the mechanisms of these governance instruments differ. While this paper has a descriptive purpose, the comparison of these channels is an interesting topic for further research. In order to get robust results from the comparison of these sources, and in order to quantify the influence of different sources of funding, we need to include indicators of financial performance, enlarge our sample with different economic periods as well as add startups which were not subject to survivorship bias.

\section{References}

1) Sukharevskaya A. Venture investments in Russia should grow tenfold by 2030. Vedomosti. 2018 . URL: https://www.vedomosti.ru/technology/ articles/2018/12/18/789646-venchurnie-investitsiirossii-virasti-desyat (In Russ.).

2) Rossi M., Festa G., Solima L., Popa S. Financing knowledge-intensive enterprises: evidence from CVCs in the US. The Journal of Technology Transfer. 2017;42(2):338-353. DOI: 10.1007/s10961-016-94952

3) Faggian A., Partridge M., Malecki E.J. Creating an environment for economic growth: creativity, entrepreneurship or human capital? International Journal of Urban and Regional Research. 2017;41(6):997-1009. DOI: 10.1111/1468-2427.12555

4) Aghion P. Entrepreneurship and growth: Lessons from an intellectual journey. Small Business Economics. 2017;48(1):9-24. DOI: 10.1007/s11187016-9812-Z

5) Vitali S., Tedeschi G., Gallegati M. The impact of classes of innovators on technology, financial fragility, and economic growth. Industrial and Corporate Change. 2013;22(4):1069-1091. DOI: 10.1093/icc/ dtt024

6) Hirsch J., Walz U. The financing dynamics of newly founded firms. Journal of Banking \& Finance. 2018. DOI: 10.1016/j.jbankfin.2018.11.009

7) Hanssens J., Deloof M., Vanacker T. The evolution of debt policies: New evidence from business startups. Journal of Banking \& Finance. 2016;65:120-133. DOI: 10.1016/j.jbankfin.2016.01.008

8) Coleman S., Cotei C., Farhat J. The debt-equity financing decisions of US startup firms. Journal of Economics and Finance. 2016;40(1):105-126. DOI: 10.1007/s12197-014-9293-3

9) Minola T., Cassia L., Criaco G. Financing patterns in new technology-based firms: An extension of the pecking order theory. International Journal of Entrepreneurship and Small Business. 2013;19(2):212233. DOI: 10.1504/IJESB.2013.054964 
10) What does a Russian IT startup look like - the "Startup Barometer 2018" study. Internet Initiatives Development Fund (IIDF). 2018. URL: https:// www.iidf.ru/media/articles/trends/kak-vyglyaditrossiyskiy-it-startap-issledovanie-startapbarometr-2018/ (In Russ.).

11) RVCA Yearbook. Market review: Private and venture investments in Russia. 2017. Russian Venture Capital Association (RVCA). 2018. URL: http://www.rvca.ru/ rus/resource/library/rvca-yearbook/ (In Russ.).

12) Venture Pulse Q4 2017: Global analysis of venture funding. KPMG Enterprise. 2018. URL: https://assets. $\mathrm{kpmg} /$ content/dam/kpmg/xx/pdf/2018/01/venturepulse-report-q4-17.pdf

13) The State of European Tech. 2018. URL: https://2018. stateofeuropeantech.com/chapter/state-europeantech-2018/article/welcome-state-europeantech-2018/

14) Cumming D., Groh A.P. Entrepreneurial finance: Unifying themes and future directions. Journal of Corporate Finance. 2018;50:538-555. DOI: 10.1016/j. jcorpfin.2018.01.011

15) Silver L., Johanson M., Berggren B. Entrepreneurial orientation, control aversion, and performance in SMEs: the contribution of equity investors. Problems \& Perspectives in Management. 2016;14(3):55-64. DOI: $10.21511 /$ ppm.14(3).2016.05

16) Lee B. Human capital and labor: The effect of entrepreneur characteristics on venture success. International Journal of Entrepreneurial Behavior \& Research. 2019;25(1):29-49. DOI: 10.1108/ IJEBR-10-2017-0384

17) Banerji D., Reimer T. Startup founders and their LinkedIn connections: Are well-connected entrepreneurs more successful? Computers in Human Behavior. 2019;90:46-52. DOI: 10.1016/j. chb.2018.08.033

18) Kim P.H., Longest K.C. You can't leave your work behind: Employment experience and founding collaborations. Journal of Business Venturing. 2014;29(6):785-806. DOI: 10.1016/j. jbusvent.2013.10.002

19) Wasserman N. The throne vs. the kingdom: Founder control and value creation in startups. Strategic Management Journal. 2017;38(2):255-77. DOI: 10.1002/smj.2478

20) Demartini P. Innovative female-led startups. Do women in business underperform? Administrative Sciences. 2018;8(4):70. DOI: 10.3390/admsci8040070

21) Edelman L.F., Manolova T., Shirokova G., Tsukanova T. The impact of family support on young entrepreneurs' start-up activities. Journal of Business Venturing. 2016;31(4):428-448. DOI: 10.1016/j. jbusvent.2016.04.003

22) Conti A., Thursby M., Rothaermel F.T. Show me the right stuff: Signals for high-tech startups. Journal of
Economics \& Management Strategy. 2013;22(2):341-

364. DOI: $10.1111 /$ jems. 12012

23) Schmid T. Control considerations, creditor monitoring, and the capital structure of family firms. Journal of Banking \& Finance. 2013;37(2):257-272. DOI: 10.1016/j.jbankfin.2012.08.026

24) Ivashkovskaya I.V. Incorporating stakeholder approach into financial analysis: The harmonized firm. Korporativnye finansy $=$ Journal of Corporate Finance Research. 2011;5(3):59-70. (In Russ.).

25) Entis L. Where startup funding really comes from (Infographic). Entrepreneur.com. 2013. URL: https:// www.entrepreneur.com/article/230011

26) Benson D., Ziedonis R.H. Corporate venture capital as a window on new technologies: Implications for the performance of corporate investors when acquiring startups. Organization Science. 2009;20(2):329-351. DOI: 10.1287/orsc.1080.0386

27) Mereminskaya E. State and state-owned companies control 70\% of the Russian economy. Vedomosti. 2016. URL: https://www.vedomosti.ru/economics/ articles/2016/09/29/658959-goskompaniikontroliruyut-ekonomiki (In Russ.).

28) Yongqi H. Startups to gain government funds. ChinaDaily.com. 2017. URL: http://www.chinadaily. com.cn/business/2017-07/28/content_30275307.htm

29) Robinson D. China puts faith in start-up boom. Financial Times. 2016. URL: https://www.ft.com/ content/11aed256-1209-11e6-91da-096d89bd2173

30) How a ranking of business incubators is made. Rusbase. 2015. URL: https://rb.ru/opinion/businessincubator/ (In Russ.).

31) World rankings 17/18 report. UBI Global. 2018. URL: https://ubi-global.com/rankings/

32) Azoulay P., Jones B., Kim D., Miranda J. Research: The average age of a successful startup founder is 45. Harvard Business Review. 2018. URL: https:// hbr.org/2018/07/research-the-average-age-of-asuccessful-startup-founder-is-45

33) Venture barometer. 2018. URL: https://vc-barometer. $\mathrm{ru} / 2018$

34) Davila A., Foster G., Gupta M. Venture capital financing and the growth of startup firms. Journal of Business Venturing. 2003;18(6):689-708. DOI: 10.1016/S0883-9026(02)00127-1

35) Fitza M., Matusik S.F., Mosakowski E. Do VCs matter? The importance of owners on performance variance in start-up firms. Strategic Management Journal. 2009;30(4):387-404. DOI: 10.1002/smj.748

36) Buchanan L. Study: U.S. businesses no longer dominate in venture capital funding. Inc.com. 2018. Available from: https://www.inc.com/leighbuchanan/american-businesses-no-longer-dominateventure-capital.html 
37) Podcerob M. Why executives are so eager to become business angels. Vedomosti. 2018. URL: https://www.vedomosti.ru/management/ articles/2018/03/15/753564-rukovoditeli-biznesangeli (In Russ.).

38) Crowdfunding in China: The financial inclusion dimension. CGAP. 2017. URL: http://documents. shihang.org/curated/zh/834091504764640588/ pdf/119207-BRI-PUBLIC-Brief-Crowdfunding-inChina-Jul-2017-0.pdf

39) Nuscheler D., Engelen A., Zahra S.A. The role of top management teams in transforming technology-based new ventures' product introductions into growth. Journal of Business Venturing. 2019;34(1):122-140. DOI: 10.1016/j. jbusvent.2018.05.009

40) Blagburn N. Why startup boards matter. Technovation. 2016;57:45-46. DOI: 10.1016/j. technovation.2016.08.007

41) Barker V.L., Mueller G.C. CEO characteristics and firm R\&D spending. Management Science. 2002;48(6):782-801. DOI: 10.1287/mnsc.48.6.782.187

42) Talaia M., Pisoni A., Onetti A. Factors influencing the fund raising process for innovative new ventures: An empirical study. Journal of Small Business and Enterprise Development. 2016;23(2):363-378. DOI: 10.1108/JSBED-07-2014-0111

43) Stepanova A, Tereshchenko A. The influence of independent directors, insider ownership and scientific connections on risky R\&D investments: Evidence from emerging markets. Korporativnye finansy = Journal of Corporate Finance Research. 2016;10(3):5-23. DOI: 10.17323/j.jcfr.20730438.10.3.2016.5-23

44) Picken J.C. From founder to CEO: An entrepreneur's roadmap. Business Horizons. 2017;60(1):7-14. DOI: 10.1016/j.bushor.2016.09.004

45) Mohan N. A review of the gender effect on pay, corporate performance and entry into top management. International Review of Economics \& Finance. 2014;34:41-51. DOI: 10.1016/j. iref.2014.06.005
46) Brinkhuis E., Scholtens B. Investor response to appointment of female CEOs and CFOs. The Leadership Quarterly. 2018;29(3):423-441. DOI: 10.1016/j.leaqua.2017.08.002

47) Boeker W., Wiltbank R. New venture evolution and managerial capabilities. Organization Science. 2005;16(2):123-133. DOI: 10.1287/orsc.1050.0115

48) Purkayastha S., Veliyath R., George R. The roles of family ownership and family management in the governance of agency conflicts. Journal of Business Research. 2019;98:50-64. DOI: 10.1016/j. jbusres.2019.01.024

49) Colombo M.G., Croce A., Murtinu S. Ownership structure, horizontal agency costs and the performance of high-tech entrepreneurial firms. Small Business Economics. 2014;42(2):265-282. DOI: 10.1007/s11187-013-9483-y

50) Cui H., Mak Y.T. The relationship between managerial ownership and firm performance in high R\&D firms. Journal of Corporate Finance. 2002;8(4):313-336. DOI: 10.1016/S09291199(01)00047-5

51) Glassner J. US VCs steer clear of Russian startups. Crunchbase.com. 2017. URL: https://news. crunchbase.com/news/us-vcs-steer-clear-russianstartups/

52) Henry Z. Like it or not, startups are soaring in Russia. Here's why. Inc.com. 2018. URL: https://www.inc. com/zoe-henry/inc-5000-europe-moscow-startupecosystem.html

53) Rodionov I.I., Gusamov S.A. Private equity performance in emerging markets. Korporativnye finansy = Journal of Corporate Finance Research. 2015;9(4):122137. DOI: 10.17323/j.jcfr.2073-0438.9.4.2015.122-137 (In Russ.). 